\title{
MOLEKULARNA IDENTIFIKACIJA VRSTA MYCOBACTERIUM TUBERCULOSIS KOMPLEKSA I NETUBERKULOZNIH MIKOBAKTERIJA
}

\author{
Đorđe Jovanović ${ }^{1}$, Vera Jovanović1 ${ }^{1}$ Irena Živanović ${ }^{2}$ \\ ${ }^{1}$ Medicinski fakultet Univerziteta u Beogradu \\ ${ }^{2}$ Mentor; Institut za mikrobiologiju i imunologiju, Medicinski fakultet Univerziteta u Beogradu
}

\section{Sažetak}

Zaključak: Primenom molekularnih tehnika za identifikaciju mikobakterija izolovanih iz respiratornih uzoraka tokom perioda od tri meseca, ustanovljeno je da je najćešće izolovana vrsta mikobakterija u Srbiji $M$. tuberculosis, a da su vrste netuberkuloznih mikobakterija (NTM) koje se izoluju iz respiratornih uzoraka lokalnih pacijenata M. gordonae, M. xenopi i M. kansasii.

Uvod: Brza i precizna identifikacija Mycobacterium tuberculosis kompleksa (MTK) i netuberkuloznih mikobakterija do nivoa vrste je od izuzetnog značaja. Visoko osetljive i specifične molekularne tehnike predstavljaju metod izbora za identifikaciju mikobakterija do nivoa vrste.

Cilj: Cilj rada je identifikacija mikobakterija izolovanih iz respiratornih uzoraka u Srbiji tokom perioda od tri meseca do nivoa vrste.

Materijal i metode: Identifikacija 112 kultura mikobakterija izvršena je primenom GenoType MTBC i CM (HAIN, Lifescience, Nemačka) testova.

Rezultati: Ukupno 88 (78,57\%) izolata je identifikovano kao vrsta $M$. tuberculosis, dok je 24 (21,43\%) izolata pripadalo NTM. Identifikacija do nivoa vrste je postignuta za $17(70,83 \%)$ izolata NTM, dok je $7(29,17 \%)$ izolata identifikovano kao Mycobacterium sp. Najčešće izolovana vrsta NTM je M. gordonae (10; 58,82\%), dok je učestalost izolovanja preostalih vrsta sledeća: $M$. xenopi (5; 29,41\%) i M. kansasii (2; 11,77\%).

Ključne reči: Mycobacterium tuberculosis kompleks, netuberkulozne mikobakterije, identifikacija mikobakterija, GenoType MTBC, GenoType CM.

\section{Abstract}

Conclusion: Identification of mycobacteria isolated from respiratory specimens over a three-month period by using molecular techniques revealed that the most frequently isolated mycobacterial species in Serbia is $M$. tuberculosis, while nontuberculous mycobacteria (NTM) species isolated from respiratory specimens of local patients are M. gordonae, M. xenopi and M. kansasii.

Introduction: Fast and accurate identification of Mycobacterium tuberculosis complex (MTBC) and nontuberculous mycobacteria to the species level is of great importance. Highly sensitive and specific molecular techniques are methods of choice for identification of mycobacteria to the level of species.

The Aim: The aim of the study was identification of mycobacteria recovered from pulmonary specimens in Serbia during a three-month period, to the level of species.

Material and methods: Identification of 112 mycobacterial cultures was performed using the Genotype MTBC and CM (HAIN, Lifescience, Germany) assays.

Results: In total, 88 (78,57\%) isolates were identified as species $M$. tuberculosis, while $24(21,43 \%)$ isolates were identified as NTM. The identification to the species level was achieved in $17(70,83 \%)$ NTM isolates, while 7 (29,17\%) were identified as Mycobacterium sp. The most frequently isolated NTM species was M. gordonae (10; $58,82 \%$ ), while the isolation rates of the remaining species were as follows: M. xenopi $(5 ; 29,41 \%)$ and M. kansasii $(2 ; 11,77 \%)$.

Key words: Mycobacterium tuberculosis complex, nontuberculous mycobacteria, identification of mycobacteria, GenoType MTBC, GenoType CM. 


\section{Uvod}

Rod Mycobacterium obuhvata veliki broj vrsta, uključujući striktno patogene, uslovno patogene i saprofitne vrste. Grupa striktnih patogena obuhvata vrste Mycobacterium tuberculosis kompleksa (MTK), koje su uzročnici tuberkuloze (TB) i M. leprae, izazivač lepre. Sve ostale vrste ovog roda nazivaju se netuberkulozne mikobakterije (NTM). MTK obuhvata blisko povezane vrste $M$. tuberculosis, M. bovis, $M$. bovis BCG, M. africanum, M. caprae, M. microti i $M$. canettii koje se, uprkos bliskoj genetskoj povezanosti, razlikuju u pogledu patogenosti i tropizma za domaćine [1]. Prirodni domaćin $M$. tuberculosis i $M$. africanum je čovek, dok, na primer, $M$. bovis može izazvati bolest kod širokog spektra domaćih i divljih životinja, poput goveda ili koza, ali takođe može biti uzročnik humane TB [2]. Najvažniji izazivač TB ljudi, kao i najčešće izolovana vrsta iz kliničkih uzoraka je M. tuberculosis. TB i danas predstavlja veliki zdravstveni problem. Svetska zdravstvena organizacija procenjuje da se svake godine prijavi oko 8 miliona novih slučajeva TB koji su uzrok smrti 1,3 miliona pacijenata, a najveći broj slučajeva TB prijavljen je u Aziji (55\%) i Africi (30\%) [3].

Veliki broj vrsta NTM prepoznat je kao izazivač mikobakterioza. U razvijenim zemljama NTM su odgovorne za većinu mikobakterijskih infekcija, kako kod imunokompromitovanih tako i kod imunokompetentnih osoba [4]. Najčešći izazivači mikobakterioza su $M$. marinum, $M$. kansasii, $M$. xenopi, $M$. fortuitum, $M$. peregrinum, M. chelonae, $M$. abscessus i M. ulcerans. Najčešće mikobakterioze su respiratorne bolesti, limfadenitis, infekcije kože, mekih tkiva i kostiju, kao i diseminovane forme bolesti [5].

Brza i precizna identifikacija MTK i NTM do nivoa vrste je od izuzetnog značaja, jer omogućava pravovremenu primenu odgovarajućeg terapijskog režima i uspostavljanje odgovarajućih mera kontrole infekcije. Laboratorijska dijagnostika mikobakterijskih infekcija zasnovana na primeni konvencionalnih metoda je dugotrajan postupak, kojim često nije moguće izvršiti identifikaciju mikobakterija do nivoa vrste. Shodno tome, visoko osetljive i specifične molekularne tehnike postale su metod izbora za identifikaciju mikobakterija do nivoa vrste. Najčešće korišćene tehnike su sekvenciranje DNK, PCR i real-time PCR, kao i testovi zasnovani na principu reverzne hibridizacije. Glavni targeti u genomu mikobakterija su 16S rRNK, hsp65 gen, ITS i rpoB gen [6]. Komercijalno dostupni testovi za molekularnu identifikaciju mikobakterija, poput GenoType testova (Hain Lifescience GmbH, Nehren, Nemačka), su od posebnog značaja za rutinsku laboratorijsku praksu. GenoType testovi su zasnovani na PCR amplifikaciji species specifičnih ciljnih sekvenci uz pomoć prajmera obeleženih bioti- nom, reverznoj hibridizaciji PCR produkata za probe imobilisane na membrani i kolorimetrijskoj detekciji hibridizovanih amplikona primenom konjugata streptavidina i alkalne fosfataze uz dodavanje odgovarajućeg supstrata. GenoType MTBC test omogućava identifikaciju vrsta MTK zasnovanu na detekciji sekvenci 23S rRNK specifičnih za članove kompleksa, species specifičnih sekvenci gyrB gena i RD1 [7]. Target za GenoType CM test (eng. common mycobacteria) je $23 \mathrm{~S}$ rRNK, na osnovu čega je moguća identifikaciju MTK i najčešće izolovanih vrsta NTM [8].

Cilj rada je identifikacija mikobakterija izolovanih iz respiratornih uzoraka u Srbiji tokom tri meseca do nivoa vrste primenom GenoType MTBC i CM testova.

\section{Materijal i metode}

U studiju je uključeno ukupno 112 kultura mikobakterija koje su izolovane iz respiratornih uzoraka tokom perioda 01.10.2013-31.12.2013. godine u Srbiji, jedna kultura po pacijentu. Ispitivane kulture mikobakterija izolovane su na Löwenstein-Jensen (LJ) i MGIT (Mycobacteria Growth Indicator Tube) podlogama. Svi izolati su identifikovani kao mikobakterije na osnovu mikroskopskih i kulturelnih karakteristika, a zatim poslati na Institut za mikrobiologiju i imunologiju Medicinskog fakulteta Univerziteta u Beogradu, radi identifikacije do nivoa vrste primenom GenoType MTBC i CM testova. Svih 112 izolata mikobakterija testirano je primenom GenoType MTBC testa, dok su izolati koji nisu identifikovani kao pripadnici MTK dalje testirani pomoću GenoType CM testa.

GenoType MTBC i CM testovi izvedeni su prema uputstvima proizvođača. Ukratko, za izolaciju DNK sa LJ podloga uzeta je po jedna eza kolonija i suspendovana u $300 \mu \mathrm{l}$ destilovane vode, dok je po $1 \mathrm{ml}$ MGIT podloga najpre centrifugiran na $13400 \mathrm{rpm}$ tokom $15 \mathrm{~min}$, a zatim je talog suspendovan u $300 \mu$ l destilovane vode. Suspenzije su inkubirane tokom 20 min u vodenom kupatilu na temperaturi od $95^{\circ} \mathrm{C}$, a nakon toga u ultrazvučnom kupatilu tokom $15 \mathrm{~min}$. Nakon centrifugiranja na 13400 rpm tokom $5 \mathrm{~min}$, po $5 \mu \mathrm{l}$ dobijenog supernatanta je korišćeno za PCR amplifikaciju. Za izvođenje PCR reakcije pripremljena je smeša od $5 \mu \mathrm{l}$ mikobakterijske DNK, $35 \mu$ prajmer-nukleotid miksa (u sastavu kita), amplifikacionog pufera sa 2,5 mM MgCl2 i 1,25 U Taq DNK polimeraze (Fermentas, UAB, Litvanija) do konačne zapremine od $50 \mu \mathrm{l}$. Parametri amplifikacije su bili sledeći: 15 min na $95^{\circ} \mathrm{C}$; deset ciklusa po 30 s na $95^{\circ} \mathrm{C}$ i 120 s na $58^{\circ} \mathrm{C}$; dodatnih dvadeset ciklusa po $25 \mathrm{~s}$ na $95^{\circ} \mathrm{C}$, $40 \mathrm{~s}$ na $53^{\circ} \mathrm{C}$ i 40 s na $70^{\circ} \mathrm{C}$; finalni ciklus ekstenzije tokom $8 \mathrm{~min}$ na $70^{\circ} \mathrm{C}$; održavanje na $6^{\circ} \mathrm{C}$. Hibridizacija je izvedena u 
uređaju TwinCubator (Hain Lifescience), koji istovremeno služi kao vodeno kupatilo i platforma za hibridizaciju. Prvi korak je denaturacija koja se postiže pripremom smeše od $20 \mu$ amplikona i $20 \mu$ reagensa za denaturaciju (u sastavu kita) u bunarčićima plastične kadice (u sastavu kita) i držanjem na sobnoj temperaturi tokom $5 \mathrm{~min}$. Nakon toga, u svaki bunarčić je dodat po $1 \mathrm{ml}$ prethodno zagrejanog pufera za hibridizaciju i postavljena obeležena traka sa fiksiranim probama. Hibridizacija je izvedena na $45^{\circ} \mathrm{C}$ tokom $30 \mathrm{~min}$. Nakon dva koraka ispiranja, u svaki bunarčić dodat je konjugat streptavidina i alkalne fosfataze i odgovarajući supstrat radi kolorimetrijske detekcije hibridizovanih amplikona.

Rezultati testova su interpretirani pomoću šablona u skladu sa uputstvima proizvođača.

\section{Rezultati}

Primenom GenoType MTBC i CM testova identifikovano je ukupno 112 kultura mikobakterija izolovanih iz respiratornih uzoraka tokom tri meseca u Srbiji. Rezultati identifikacije prikazani su na grafikonu 1. Od 112 izolata mikobakterija, $88(78,57 \%)$ je identifikovano kao vrsta $M$. tuberculosis, dok su preostala $24(21,43 \%)$ izolata identifikovana kao NTM. Identifikacija NTM do nivoa vrste je postignuta za 17 (70,83\%) izolata, dok 7 $(29,17 \%)$ izolata primenom GenoType CM testa nije moglo biti identifikovano do nivoa vrste i označeni su kao Mycobacterium sp. Identifikovano je ukupno 3 vrste NTM. Najčešće izolovana vrsta NTM je M. gordonae (10; $58,82 \%)$, dok je učestalost izolovanja preostale dve vrste NTM sledeća: M. xenopi $(5 ; 29,41 \%)$ i M. kansasii (2; 11,77\%) (grafikon 2).

Grafikon 1. Rezultati identifikacije 112 kultura mikobakterija primenom GenoType MTBC i CM testova.

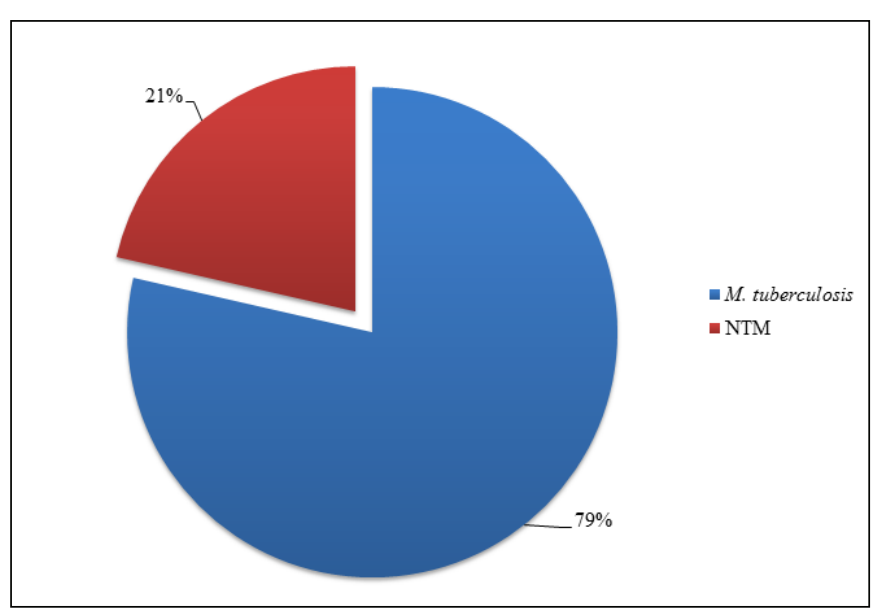

Grafikon 2. Rezultati identifikacije 17 izolata NTM do nivoa vrste primenom GenoType CM testa.

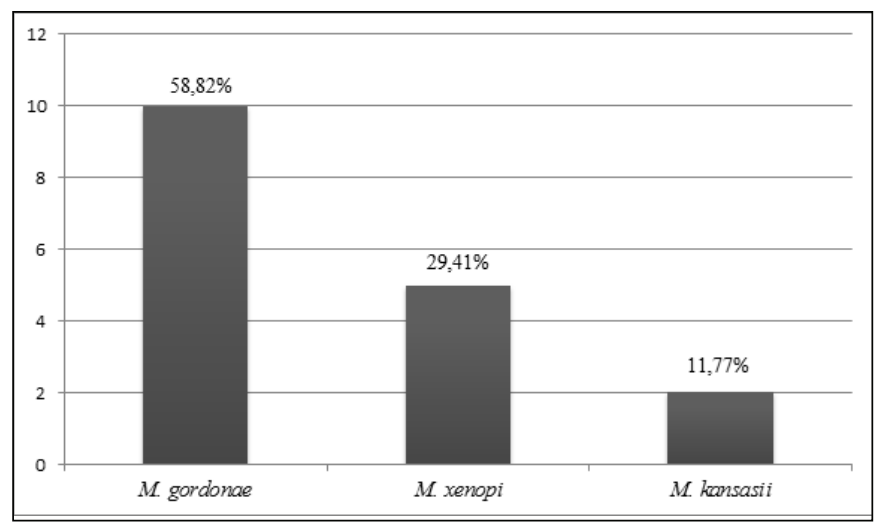

\section{Diskusija}

Rezultati primene GenoType MTBC i CM testova za identifikaciju mikobakterija izolovanih iz respiratornih uzoraka u Srbiji tokom perioda od tri meseca, pokazali su da je najčešće izolovana vrsta mikobakterija u Srbiji M. tuberculosis. Ovakav rezultat bio je očekivan, s obzirom da je $M$. tuberculosis najčešće izolovana vrsta mikobakterija iz respiratornih uzoraka u svetu. Odsustvo drugih vrsta MTK među lokalnim izolatima je takođe donekle očekivan rezultat. M. africanum je uzročnik oko 40\% TB kod ljudi u zapadnoj Africi [9] i retko je izolovan u evropskim zemljama. Prisustvo $M$. africanum $\mathrm{u}$ oblastima van zapadne Afrike je uglavnom detektovano u uzorcima emigranata iz ovog regiona [9]. Iako $M$. $t u$ berculosis i $M$. canettii imaju identične profile u GenoType MTBC testu, detekcija M. canettii među lokalnim izolatima MTK nije bila očekivana, jer ova vrsta spada $\mathrm{u}$ retko izolovane vrste MTK, uglavnom kod pacijenata sa područja Afrike [10]. M. microti takođe spada u retko izolovane vrste MTK i najčešće je detektovan kod imunodeficijentnih osoba obolelih od TB [10]. Identifikacija $M$. bovis je bila očekivana, s obzirom da je prisustvo ove vrste kao uzročnika humane TB u Evropi dokumentovano [11], međutim ova vrsta MTK nije identifikovana $\mathrm{u}$ ispitivanom uzorku. Takođe, nije identifikovan ni $M$. caprae, iako je i ova vrsta MTK prepoznata kao izazivač TB kod ljudi koji su u kontaktu sa životinjama u različitim, posebno ruralnim, delovima Evrope [12].

Primenom GenoType CM testa, do nivoa vrste identifikovano je ukupno 17 (70,83\%) izolata NTM, dok je 7 (29,17\%) identifikovano kao Mycobacterium sp. Najčešće izolovane vrste NTM u plućnim uzorcima tokom perioda 01.10.2013-31.12.2013. godine u Srbiji su $M$. gordonae i M. xenopi. Van der Werf i saradnici su pokazali da je $M$. gordonae najčešće identifikovana vrsta NTM u plućnim uzorcima u Hrvatskoj i Luksembur- 
gu, a u Italiji i Sloveniji vrsta $M$. xenopi, što je u skladu sa našim rezultatima [13]. M. xenopi se retko izoluje u Sjedinjenim Američkim Državama, ali predstavlja drugu najčešće izolovanu vrstu NTM u Evropi i Kanadi [5]. Interesantno je da $M$. gordonae predstavlja vrstu NTM koja se najčešće izoluje iz uzoraka kao kontaminant [14]. Osim M. xenopi i M. gordonae, u našoj studiji je identifikovana i vrsta $M$. kansasii. Učestalost izolovanja navedenih vrsta NTM odgovara rezultatima drugih studija [5]. Međutim, 29,17\% NTM nije identifikovano do nivoa vrste. Ovi izolati odgovarali su profilu Mycobacterium sp. Prema uputstvu proizvođača testa korišćenog u ovom istraživanju, izolati sa ovakvim profilom najverovatnije su mikobakterije kontaminanti iz okruženja.

Primenom molekularnih tehnika za identifikaciju mikobakterija izolovanih iz respiratornih uzoraka tokom perioda od tri meseca, ustanovljeno da je najčešće izolovana vrsta mikobakterija u Srbiji M. tuberculosis, a da su vrste NTM koje se izoluju iz respiratornih uzoraka lokalnih pacijenata M. gordonae, M. xenopi i M. kansasii.
10. Brosch R, Gordon SV, et al. A new evolutionary scenario for the Mycobacterium tuberculosis complex. Proceedings of the National Academy of Sciences of the United States of America. 2002; 99;6: 3684-9.

11. Smith NH. The global distribution and phylogeography of Mycobacterium bovis clonal complexes. Infection, genetics and evolution : journal of molecular epidemiology and evolutionary genetics in infectious diseases. 2012; 12;4: 857-65.

12. Prodinger WM, Eigentler A, Allerberger F, Schonbauer $\mathrm{M}$, Glawischnig W. Infection of red deer, cattle, and humans with Mycobacterium bovis subsp. caprae in western Austria. Journal of clinical microbiology. 2002; 40;6: 22702.

13. Van der Werf MJ, Kodmon C, et al. Inventory study of non-tuberculous mycobacteria in the European Union. BMC infectious diseases. 2014;14:62.

14. Mazumder SA, Hicks A, Norwood J. Mycobacterium gordonae pulmonary infection in an immunocompetent adult. North American journal of medical sciences. 2010; 2;4: 205-7.

\section{Literatura}

1. Wirth T, Hildebrand F, et al. Origin, spread and demography of the Mycobacterium tuberculosis complex. PLoS pathogens. 2008; 4;9: e1000160.

2. Muller B, Durr S, et al. Zoonotic Mycobacterium bovis-induced tuberculosis in humans. Emerging infectious diseases. 2013; 19;6: 899-908.

3. World Health Organization (WHO). Global tuberculosis report 2013. Geneva: WHO; 23 Oct 2013. Available from: http://apps.who.int/iris/bitstre am/10665/91355/1/9789241564656_eng.pdf

4. Glassroth J. Pulmonary disease due to nontuberculous mycobacteria. Chest. 2008; 133;1: 243-51.

5. Griffith DE, Aksamit T, et al. An official ATS/IDSA statement: diagnosis, treatment, and prevention of nontuberculous mycobacterial diseases. American journal of respiratory and critical care medicine. 2007; 175;4: 367-416.

6. Perez-Osorio AC, Boyle DS, et al. Rapid identification of mycobacteria and drug-resistant Mycobacterium tuberculosis by use of a single multiplex PCR and DNA sequencing. Journal of clinical microbiology. 2012; 50;2: 326-36.

7. Richter E, Weizenegger M, Fahr AM, Rusch-Gerdes S. Usefulness of the GenoType MTBC assay for differentiating species of the Mycobacterium tuberculosis complex in cultures obtained from clinical specimens. Journal of clinical microbiology. 2004; 42;9: 4303-6.

8. Richter E, Rusch-Gerdes S, Hillemann D. Evaluation of the GenoType Mycobacterium Assay for identification of mycobacterial species from cultures. Journal of clinical microbiology. 2006; 44;5: 1769-75.

9. De Jong BC, Antonio M, Gagneux S. Mycobacterium africanum--review of an important cause of human tuberculosis in West Africa. PLoS neglected tropical diseases. 2010; 4;9: e744. 